DOI: 10.4274/tpa.45.232

\title{
Eozinofilik özofajit
}

Eosinophilic esophagitis

Yeditepe Üniversitesi Tip Fakültesi, Çocuk Sağı̆̆̆ı ve Hastalıkları Anabilim Dalı, Çocuk Gastroenteroloji, Hepatoloji ve Beslenme Bilim Dall, İstanbul, Türkiye *Yeditepe Üniversitesi Tıp Fakültesi, Çocuk Sağlığı ve Hastalıkları Anabilim Dalı, İstanbul, Türkiye

\section{Özet}

Eozinofilik özofajit, giderek daha çok dikkati çekmekte olan, yeni fark edilmiş bir bozukluktur. Hastalar gastroözofageal reflü bulguları gösterirler, bilinen ya da daha karmaşık reflü tedavilerine yanıt vermezler. Endoskopik ve histopatolojik belirteçlerin yanı sıra, belirtileri içeren tanısal klavuzların geliştirilmesi, klinisyenlerin farkındalığını ve tanı koyulan eozinofilik özofajit sayısını artırmıştır. Eozinofilik özofajitin gastroözofageal reflü hastalığından klinik olarak ayrımındaki zorluklar daha belirginleşmiş ve daha bireysel tedavi seçeneklerine intiyaç duyulmaya başlanmıştır. Hastaların \%90'ında neden gıda alerjileridir. Hastalı̆̆ın patojenezinin daha iyi şekilde anlaşılması klinik olarak tanımlanmasını sağlayarak tanısal yeterliliği arttıracak ve sonuçta hastaların daha iyi tedavi edilmesini sağlayacaktır. (Türk Ped Arş 2010; 45: 232-7) Anahtar sözcükler: Çocukluk çağı, gıda alerjileri, eozinofilik özofajit

\section{Summary}

Eosinophilic esophagitis is a recently recognized disorder receiving increasing attention. Patients present with symptoms of gastroesophageal reflux and are not responsive to standard or aggressive reflux medications. Development of diagnostic guidelines consisting of symptoms as well as endoscopic and histopathologic criteria has improved the awareness of clinicians and the diagnosis of eosinophilic esophagitis. The clinically challenging discrimination of eosinophilic esophagitis from gastroesophageal reflux disease has become more obvious and has avoked the need for more individualized therapy options. Food allergies are causative in more than $90 \%$ of patients. A better understanding of the pathogenesis of this disorder would improve the clinical recognition and diagnostic adequacy and ultimately provide patients with more optimal treatment options. (Turk Arch Ped 2010; 45: 232-7)

Key words: Childhood, eosinophilic esophagitis, food allergies

\section{Giriş}

Eozinofilik özofajit (EÖ), sindirim sisteminin başka hiçbir yerinde olmayıp sadece özofagusun eozinofiller ile tutulumu olarak tanımlanır. İlk EÖ olgusu 1977'de tanımlanmış ve geçtiğimiz yıllar içinde bu hastalıkla ilgili yayınlar artmıştır. Eozinofilik özofajit bulguları, gastroözofageal reflü hastalığı (GÖRH) ile benzerdir. Bunların arasında kusma, karın ağrısı, regürjitasyon, besin sıkışması ve yutma güçlüğü bulunur. Ancak EÖ, bilinen GÖRH tedavisine yanıtsız olup pH normaldir (1).

\section{Epidemioloji}

Eozinofilik özofajit'in yaygınlığı tam olarak bilinmemektedir. ABD'de tahmini yaygınlık çocuklarda 4,3/105 ve eriş- kinlerde 2,5/105 bulunmuştur (2,3). Gastroözofageal reflü hastalı̆ına sahip hastaların yaklaşık \%6-10'unda gerçek tanının EÖ olduğunu öne süren çalışmalar vardır (4).

Eozinofilik özofajit'li çocukların çoğunun erken çocukluk çağında tanı aldığı bildirilmiştir. Biyopsi ile ilk tanılarını alan hastaların \%68'i altı yaş altındaki çocuklar olup olguların \%36'sı üç yaşın altındadır. Erkekler kızların yaklaşık üç katı sıklıkta EÖ tanısı almaktadır (5).

Eozinofilik özofajit hastalarının yaklaşık \%60-70'i tipik olarak artmış IgE düzeyi, periferik eozinofili, astım, atopik dermatit ve alerjik rinit gibi alerjik hastalık ve pozitif deri testine sahip alerjik geçmişi olan erkeklerdir $(6,7)$.

Eozinofilik özofajit'li çocukların demografik özellikleri Tablo 1'de özetlenmiştir (5).

Yazışma Adresi/Address for Correspondence: Dr. E. Mahir Gülcan, Yeditepe Üniversitesi Hastanesi, Devlet Yolu Ankara Cad. No: 102/104, 34752, Kozyatağı, İstanbul, Türkiye

E-posta: mgulcan@yeditepe.edu.tr Geliș Tarihi/Received: 10.07.2010 Kabul Tarihi/Accepted: 17.07.2010

Türk Pediatri Arşivi Dergisi, Galenos Yayınevi tarafindan basılmışıtr. / Turkish Archives of Pediatrics, published by Galenos Publishing. 


\section{Etioloji}

Eozinofilik özofajit etiolojisinde gıda alerjisinin gösterildiği ilk olgular erişkinlerde 1977 'de (8), çocuklarda ise 1995'de (9) tanımlanmıştır.

Eozinofilik özofajit'e neden olan gıda alerjilerine ait ilk kanıt Kelly ve ark.'ları (9) tarafından yapılan çalıșmada gösterildi. Çalıșmada inatçı GÖRH ve EÖ'sü olan 10 çocukta elementel mama uygulanması sonucunda bu çocukların bulgularında ve biyopsilerinde kısmi veya tam iyileşme olduğu gösterildi. Markowitz ve ark.'ları (10) kronik GÖRH olan 346 çocuk içinde 51'inde EÖ saptayarak bu sonuçları doğruladı. Elementel mama verilen bu çocukların tamamına yakınında bulgular bir hafta içinde düzeldi. Bir ay sonra yapılan kontrollerinde distal özofagustaki eozinofil sayısında anlamlı bir düşme saptandı.

Liacouras ve ark.'ları (11) 389 EÖ'lü çocukta yaptıkları çalışmada, hastaların bir grubuna elementel diyet ve diğer gruba da prick deri testi ve atopi yama testine göre "eliminasyon" diyeti vermişler, flutikazon propiyonat verilen grup ile karşılaştııılığında bulguların ve biyopsilerdeki eozinofil düzeylerinin düzelmesi şeklindeki tedavi yanıtını elementel diyet alan grupta \%97 olarak saptamışlar, ilaç tedavisi alan grupta ise değişiklik görmemişlerdir. Bu bulgular EÖ'de elementel diyetin ilaç tedavisine üstün olduğunu göstermiştir. Çalışmada özofagus biyopsilerinin normale dönmesinden sonra alerjik gıdaların tekrar verilmesiyle klinik bulguların ve özofageal eozinofilinin tekrarlaması, çocuklarda gıda alerjisinin EÖ nedeni olduğunun kesin kanıtı olarak gösterilmiştir.

Tablo 1. Eozinofilik özofajitli hastaların demografik özellikleri (2)

\begin{tabular}{|l|c|}
\hline Erkek (\%) & 75 \\
\hline Kız (\%) & 25 \\
\hline Ortalama yaş (en küçük- en büyük) (yıl) & $6,2(0,25-17,7)$ \\
\hline Irk (\%) \\
\hline Beyaz & 90 \\
\hline Afro-amerikan & 4 \\
\hline Asyalı & 3 \\
\hline Diğer & 3 \\
\hline
\end{tabular}

Tablo 2. Eozinofilik özofajitli çocuklarda saptanan besin alerjileri (12-14)

\begin{tabular}{|l|c|}
\hline Besin & $\%$ \\
\hline Süt & 17 \\
\hline Yumurta & 11 \\
\hline Buğday & 9,6 \\
\hline Soya & 7,8 \\
\hline Misır & 7,8 \\
\hline Sığır eti & 6.6 \\
\hline Tavuk & 6,1 \\
\hline Yer fistığı & 5,4 \\
\hline Patates & 4.8 \\
\hline Pirinç & 4,1 \\
\hline
\end{tabular}

Spergel ve ark.'ları (5) EÖ tanılı çocuklarda prick deri testi ve atopi yama testi kullanarak süt, yumurta, buğday, mısır, sığır eti, tavuk, arpa, yulaf, pirinç ve yer fıstığı alerjisi tanımlamaya çalışmışlar, daha önceki çalışmalarda saptanan süt, yumurta, buğday, soya, mısır, sığır eti ve tavuk alerjisi (12-14) bu çalışmada da hastaların 2/3'ünde pozitif saptanmıştır. Eozinofilik özofajitli hastalarda en yaygın saptanan 10 besinin alerji oranları Tablo 2'de görülmektedir.

\section{Patojenez}

Eozinofilik özofajitin patojenezi tam olarak bilinmemekle birlikte yangllı özofageal dokunun incelenmesinde artmış bir IL-5 ekspresyonu ve benzer bir IL-4 ve IL-13 ekspresyonu görülür. İL-5 güçlü bir eozinofilik büyüme faktörü olduğundan, doku düzeyinde eozinofilleri koruyabilir. Yapılan son çalışmalarda gen-çip incelemesinde belirgin bir eotaksin-3 artışı bulunmuştur. Eotaksin-3 düzeyleri doku eozinofilisi ve mast hücre sayısı ile bağlantılıdır ve eozinofiller için bir kemokin olması, onun EÖ patojenezinde önemli bir molekül olduğunu düşündürür. Eozinofilik özofajit hastalarında eotaksin-3 geni üzerinde tek-nükleotid polimorfizmi bulunmuştur. Bu bulgu EÖ topluluğunun \%14'ünün belli bir genetik polimorfizme bağlı olduğunu düşündürür (1).

Yiyecek alerjenleri ve aeroalerjenler muhtemelen $T$ hücre aktivasyonuna ve anahtar IL-5 ve IL-13 üretimine sebep olarak eozinofil hareketini, aktivasyonunu ve ömrünü, lgE üretimini ve aktive epitelyumden eotaksin-3 üretimini artırmaktadır. Eotaksin-3, damar hücre adezyon molekülü-1 (VCAM-1) ile aktive olmuş damarlarla birlikte kan damarlarının artışına ve eozinofil birikimine olanak sağlar. Tümör nekrozis faktör- $\alpha$ (TNF- $\alpha$ ) VCAM-1 üretimini artırabilir. Ana temel protein (MBP) gibi eozinofil granül ürünleri epitelyum hiperplazisini teşvik etmek için fibroblast büyüme faktör 9'u (FGF9) artırabilir ve transforming büyüme faktör- $\beta 1$ (TGF- $\beta 1$ ) gibi pro-fibrotik faktörlerin eozinofillerden salgılanması subepitelyal fibroza sebep olabilir (15).

\section{Klinik}

Eozinofilik özofajitin bulguları yaşa bağlı olarak değişir. Erişkinlerde hastalık tipik olarak disfaji ve besin sıkışması ile ortaya çıkar $(16,17)$. Desai ve ark.' ları (18) besin sıkışması olan 31 hastanın 17'sine klinikopatolojik olarak EÖ tanısı koymuşlar, bu 17 hastanın tümünde de dakikalar ile saatler arasında değişen sürelerde disfaji olduğunu saptamışlardır. Diğer geniş erişkin serilerinde de benzer bulgular gösterilmiştir (19-21).

\begin{tabular}{|l|l|}
\hline Tablo 3. & $\begin{array}{l}\text { Eozinofilik özofajitli çocuklarda yaşa göre sık } \\
\text { karşılaşılan klinik bulgular (15) }\end{array}$ \\
\hline Süt çocuğu & $\begin{array}{l}\text { Besini reddetme veya tahammülsüzlük, huzursuzluk, } \\
\text { kusma, gelişme geriliği }\end{array}$ \\
\hline Çocuk & $\begin{array}{l}\text { Karın ağrısı, kusma, GÖRH'ye benzer belirtiler, zor } \\
\text { yutma, besinlerden iğrenme/sınırlı diyet, büyüme geriliği }\end{array}$ \\
\hline Ergen & $\begin{array}{l}\text { Disfaji, özofagusta besin sıkışması, bulantı, GÖRH'ye } \\
\text { benzer belirtiler, sınırlı diyet }\end{array}$ \\
\hline Erişkin & Disfaji, özofagusta besin sıkışması \\
\hline
\end{tabular}


Çocuklarda, karın ağrısı, göğüs ağrısı, besin sıkışması, gelişme geriliği, kusma ve asit önleme tedavisine yanıt vermeyen GÖRH benzeri bulgular gibi birçok belirtiyle ortaya çıkabilir. Bulguların bu kadar çeşitli olması özofageal dismotiliteye bağlı olduğu düșünülse de, bu durumu tam olarak aydınlatabilmek çocuklarda zordur (22).

Tablo 3'de çocukluk yaş grubunda yaşlara göre klinik bulgular özetlenmiş̧ir (15).

Spergel ve ark.'ları (5) 14 yıllık takip içeren 330 EÖ tanısı alan hastada belirtileri büyüme geriliği veya beslenmeyi reddetme, GÖR veya kusma, karın ağrısı, disfaji ve besin sıkışması olarak dört gruba ayırmışlar, GÖRH/kusma küçük okul çağı çocuklarında görülürken, disfaji ve besin sıkışması büyük çocuklarda saptanan bulgular olarak ortaya çıkmış, çok küçük çocuklarda görülen büyüme geriliği/beslenme zorluğu ile GÖRH benzeri belirtiler en sık görülen bulgular olmuştur.

\section{Laboratuvar}

Endoskopik bulgular: Eozinofilik özofajit ile ilgili tanı koydurucu endoskopik bulgular olmamasın arağmen, EÖ olduğu şüphelenilen bir hastanın değerlendirilmesinde ilk tanısal basamak üst sindirim sistemi endoskopisidir. Kırmızı çizgilenmeler, beyaz eksüdalar, uzunlamasına makaslama, kırılganlık, krepon kağıdı mukoza, küçük çaplı özofagus, Schatzki halkası, kıvrımlanmış veya halkalanmış özofagus ve soliter halkaları içeren EÖ ile ilişkili çok sayıda endoskopik özellik tanımlanmıştır (23). Beyaz eksüda ve uzunlamasına çizgilenme, lokal ödem ve akut enflamasyona ikincil gelişir. Krepon kağıdı mukoza/kırılgan mukoza ve darlık ise kronik eozinofilik enflamasyonun muhtemel bir sonucudur (24). Resim 1'de EÖ'de görülen endoskopik bulgular yer almaktadır (23-25).

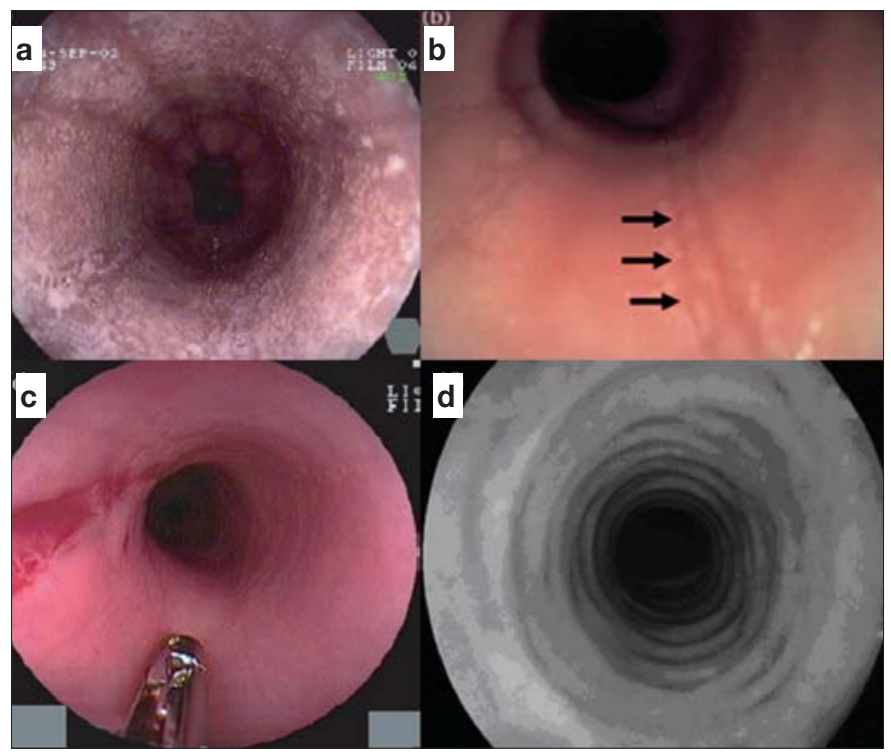

Resim 1. Eozinofilik özofajit'de endoskpik görünümler:

(a) beyaz eksüda, (b) uzunlamasına kırmızı çizgilenme, (c) kırılgan, krepon kağıdı mükoza (biyopsi forsepsinin dokunmasından sonra lasere olmuş), (d) halkalanmış özofagus (23-25)
Strauman ve ark.'ları (26) EÖ'nün altı endoskopik işareti olan beyaz eksüda, kırmızı çizgilenmeler, oluklu halkalar, soliter halkalar, krepon kağıdı işaret ve ciddi darlık bulgularını değerlendirdikleri çalışmalarında ilk tanıda (aktif enflamasyon altında) beyaz eksüda ve kırmızı çizgilenmelerin en belirgin bulgu olduğunu, topikal kortikosteroid (budesonid) tedavisi sonrası histolijik remisyondan sonra ise beyaz eksüdaların tüm hastalarda, kırmızı çizgilenmelerin ise hastaların tamamına yakınında kaybolduğunu saptamışlardır.

Histolojik bulgular: Eozinofilik özofajitin histolojik tanı belirteçlerinde ortak bir görüş bulunmamaktadır. En yaygın görüş, EÖ’nün klinikopatolojik bir hastalık olduğu ve tanısının hastalığa özgü tipik belirtiler ile birlikte belirgin histolojik bulgular (>20 eozinofil/büyük büyütme alanı) varlığında proton pompa inhibitörlerine (PPI) yanıt vermeme ile konabileceğidir. Geleneksel olarak, epitelyum içi eozinofillerin saptanması GÖRH ile ilişkilidir, fakat son 10 yıllık zamanda $>20$ eozinofil/büyük büyütme alanı sayısı, eozinofilik mikro apseler, duvar yüzeyi boyunca eozinofillerin yüzeyel tabakalaşması, bazal bölge hiperplazisi ve artmış papilla boyutları, klinik bulguların tam olduğu koşullarda EÖ tanısını büyük oranda koydurmuştur. Tanı için gastrik ve duodenal biyopsiler normal olmalı, sadece özofagus tutulumu olmalıdır (27-29).

Resim 2'de EÖ'lü çocuklarda hematoksilen-eozin boyaması ile özofagusta saptanan artmış epitelyum içi eozinofiller görülmektedir (30).

\section{Tanı ve ayırıcı tanı}

Eozinofilik özofajit tanısı, klinikopatolojik tanıma bağlıdır. Eozinofiller özofagusta normal olarak bulunmazken, sindirim sisteminin başka yerlerinde normalde saptanabilir (31). Eozinofilik özofajitin bilinen tanımı, bir büyük büyütme alanında 20 'den fazla eozinofil bulunmasına dayanır (32). Ancak bazı çalışmalarda bu değer 15 ile 24 eozi-

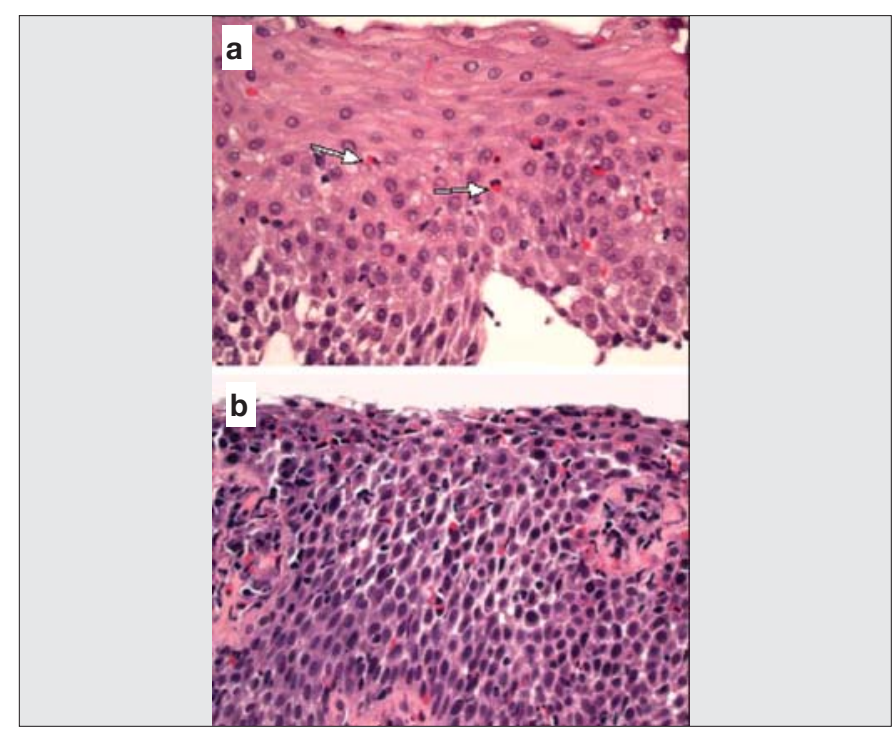

Resim 2. Eozifilik özofajitli olgularda özofageal eozinofili (Hematoksilen-eozin, x400) (30) 
nofil arasında değişiklikler gösterebilmektedir (33). Ayrıca özofagus tutulumu yamalı tarzdadır ve tanıda en yüksek duyarlılık için özofagustan alınacak en az beş biyopsi en uygun sayıdır (34). Bir diğer histolojik özellik ise EÖ'lü hastalarda normal bireyler veya GÖRH'ye kıyasla şiddetli bazal hücre hiperplazisi olmasıdır (35).

\section{İmmün aracılıklı sindirim sistemi hastalığının değerlendirilmes} (eozinofilik özofajit)

Klinik öykü ve fizik muayene GÖR veya özofajit bulguları

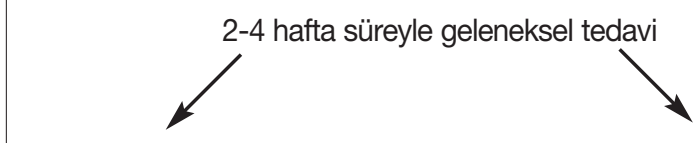

Olumlu yanit

$(-)$

$\downarrow$

Eozinofilik özofajiti değerlendir

$\downarrow$

Üst endoskop

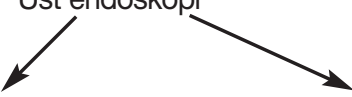

Patoloji eozinofolik

özofajiti gösterir

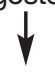

Özofagus PH

monitörizasyonu

(antireflü ted. bitiminde

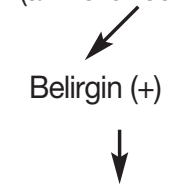

- GÖR'ü ted. et.

- Astma araştır
Normal özofagus

eozinofil artış yok

Diğer tanıları düşün

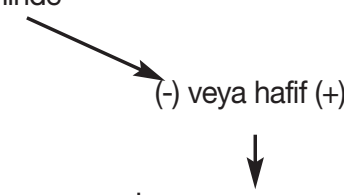

İmmün hastalıkları değerlendir

- Prick testleri (lgE)

- Yama testleri (T hücresi)

- Astma araştır

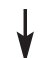

Diyetten dört hafta eliminasyon: - Sadece elementel formüla veya

- İmmün tarama temelinde seçilmiş besinleri dışla

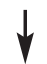

Klinik yanıtı değerlendir Endoskopiyi tekrarla
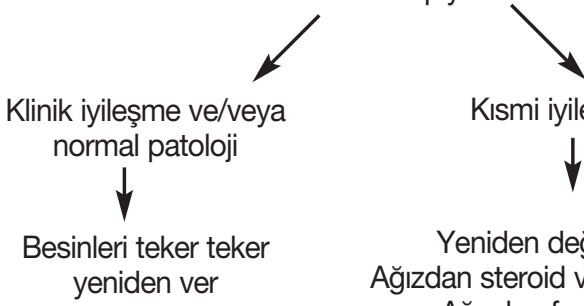

Kısmi iyileşme

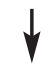

Yeniden değerlendir: Ağızdan steroid veya elementel Ağızdan formüla ver

Şekil 1. Eozinofilik özofajitli hastanın değerlendirilmesi (41)
Endoskopik özellikler, laboratuvar bulguları, özofagusdaki eozinofil sayısı gibi belirteçler EÖ için doğrudan tanı koydurucu olmadığından EÖ tanısı sadece bir bulguya göre koyulamaz. Eozinofilik özofajit hastalığı için tanısal klavuz olarak kullanılabilecek belirteçler şunlardır: (1) klinik (özofageal disfonksiyon belirtileri): göğüs ağrısı, karnın üst kısmında ağrı, kusma, yeme reddi, regürjitasyon, büyüme geriliği ve ishal; (2) histoloji: Bir büyük büyütme alanında en azından 15 eozinofil saptanması; (3) GÖR'ün dışlanması: Yüksek doz PPI'ye yanıtsızlık ve normal $\mathrm{pH}$ monitörizasyonu; (4) özofageal eozinofiliye yol açan diğer durumların dışlanması (36).

Son yıllarda EÖ tanısı için girişimsel olmayan göstergeler geliştirilmesi için çalışılmakta ve serum İgE, CD23, eotaksinler, İL-5, ana temel protein, eozinofil katyonik protein, eozinofil peroksidaz ve eozinofilden elde edilen nörotoksin gibi bazı biyokimyasal göstergelerin hastalığın ortaya çıkış şekli, iyileşme, şiddet ve tedaviye yanıt ile uyumlu olduğu gösterilmiştir. Yine EÖ'lü hastaların \%67'sinde periferik kanda eozinofili olabileceği gösterilmiştir $(37,38)$.

Eozinofilik özofajit ve GÖR arasında klinik pratikte ayrım yapmak genelde zordur. Asite maruz kalmak özofagus epitelyumundan kemokinlerin salınmasına, böylece eozinofillerin o bölgeye çekilmesine neden olur. Genellikle distal özofagustaki hafif eozinofili GÖR'de sık görülür. Böyle bir hastada $\mathrm{pH}$ monitörizasyonunda asit reflü saptanması, GÖR ile uyumlu klinik bulgular var ise, PPI tedavisi ile eozinofilik tutulum düzeliyorsa, tanı GÖRH'dır (39).

Ayrıca alerjik rinit, özofagusta eozinofillere neden olabilir. Literatürde bir büyük büyütme alanında 40'a kadar eozinofil saptanan ve EÖ'ye neden olan bir polen duyarlılığı olgusu bildirilmiştir (40).

Eozinofilik özofajit değerlendirilmesinde izlenecek akış şeması Şekil 1'de özetlenmiştir (41).

\section{Tedavi}

1. Diyet tedavisi:

Elementel diyet: Eozinofilik özofajitli çocuklarda amino asit bazlı elementel mamaların hem klinik bulguları hem de özofageal eozinofiliyi azalttığı gösterilmiştir (24).

Eliminasyon diyeti: Deri prict test ve atopi yama testi ile saptanan besinsel alerjenlere göre yapılan besin eliminasyon diyetleri de EÖ tedavisinde klinik ve histolojik düzelmeyi sağlamıştır (37).

2. Sistemik steroidler:

Eozinofilik özofajitin yeni bir klinik durum olarak tanımlanmasından hemen sonra eozinofilik enflamasyonun kortikosteroid tedavisine yanıt verdiği gösterilmiştir (23). Tedavide sistemik steroidlerin etkili olduğu, sistemik kortikosteroidlerin klinik bulguları ve özofageal histolojiyi anlamlı olarak iyileştirdiği saptanmıştır. Ancak hastalık steroid tedavisi kesildikten sonra tekrarlayabilmektedir. Yan etkiler ve ilacın kesilmesinden sonra hastalığın tekrarlaması nedeni ile EÖ tedavisinde kullanımları sınırlı kalmıştır (37). 


\section{Topikal steroidler:}

Topikal kortikosteroidlerin belirtileri ve akut alevlenmeleri hem erişkinlerde hem de çocuklarda iyileştirdiği gösterilmiştir (42). Çocuklarda plasebo ile karşılaştııılığında topikal flutikazon ile EÖ'lü hastaların \%55'inde remisyon elde edilirken plasebo grubunda bu oran sadece $\% 9$ olmuştur (43). Yine benzer şekilde topikal budesonid ile tedavi edilen erişkinlerde tedavi ve plasebo grubunda histolojik düzelme sırası ile $\% 72$ ve $\% 11$ olarak bulunmuştur. Sistemik (ağızdan prednizon) ve topikal kortikosteroid (flutikazon) ile tedavi edilen EÖ'lü çocuklarda sistemik tedavi verilenlerin \%93,82'sinde, topikal tedavi verilenlerin ise \%94,4'ünde histolojik yanıt alınırken klinik yanıt oranları sırası ile \%100 ve ve \%97,2 olarak bulunmuşyur (44). Yan etki olarak prednizon alan hastaların \%40'ında sistemik yan etkiler oluşurken flutikazon grubunda sadece özofageal kandidiyaz görülmüştür.

\section{Diğer seçenek tedaviler:}

Lökotriyen inhibitörleri: Lökotriyenler eozinofilleri dokuya çekerler ve lökotriyenlerin engellenmesi eozinofili göçünü ve birikimini azaltabilir. Montelukast ile yapılan çalışmalarda geleneksel tedavilere yanıtsız hastalarda tam iyileşme gösterilmiştir. Zafirlukast ve diğer lökotriyen inhibitörleri ile Churg-Strauss sendromu arasında bir ilişki saptanmış, ancak bu ilişki montelukast ile görülmemiştir. Bu nedenle EÖ'lü hastalarda lökotriyen inhibitörlerinin kullanımının riskleri ve faydalarıın araştıııdığı daha fazla çalışmaya intiyaç vardır (37).

Biyolojikler: IL-5, eozinofil hareketini özofagusa yönlendiren ve diğer majör eozinofilik işlevleri de düzenleyen bir sitokindir. Mepolizumad gibi IL-5'e karşı geliştirilen monoklonal antikorlar, steroide dirençli hastalarda yeni bir tedavi fırsatı olabilir. Tümör nekrozis faktör-alfa inhibitörü olan infliksimab ile yapılan çalışmalar ise bekleneni karşılayamamıştır (23).

İmmünmodülatörler: Azatiyoprin ve 6-merkaptoprin gibi immünsüpresifler ile yapılan ileriye dönük çalışmalar olmakla birlikte olgu sunumlarında steroide dirençli hastalarda remisyon sağladığı gösterilmiştir (45).

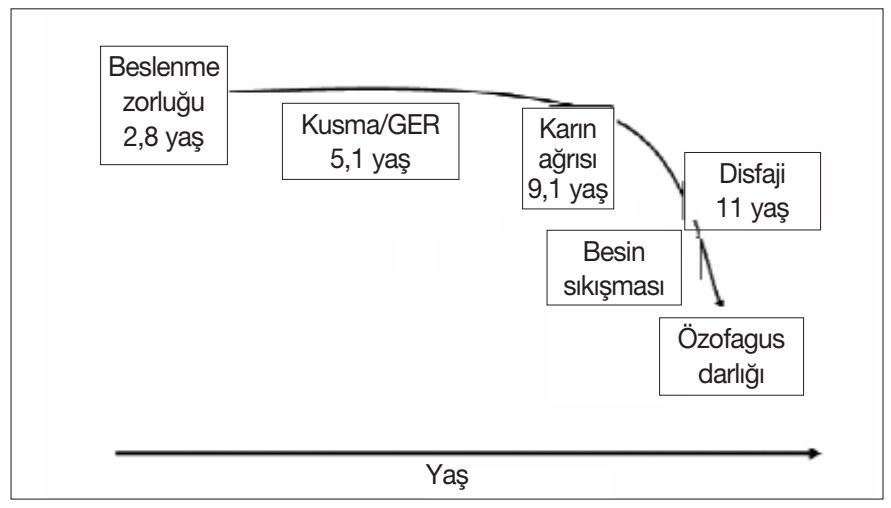

Şekil 2. Çocukluklarda eozinofilik özofajitin doğal seyri (5)

\section{Seyir}

Eozinofilik özofajitli hastaların uzun süreli izlemleri ile ilgili bilgiler çok az olmakla birlikte eldeki veriler hastalığın kronik bir hastalık olduğunu düşündürmektedir. Tek başına özofageal darlık veya tüm özofagusta daralma, bugüne kadar bildirilen tek komplikasyondur. Bu daralma özofagus boyunca olursa, küçük çaplı özofagus adını almaktadır ve bu durum kolajen birikimi ile sürekli devam eden eozinofilik enflamasyonun sonucunda gelişen fibroz oluşumuna bağlıdır. Uzun süre izlenen (11,5 yıl) hastaların yaklaşık \%50'sinde daralma saptanmaktadır ve tıbbi tedaviye yanıtsızdır. Bu komplikasyonun oluşumu için eozinofilik enflamasyonun yıllarca sürmesi gerektiğinden özofagusta daralma, çocuklarda yaygın değildir. Özofagus karsinomu EÖ'lü hastalarda bildirilmemiş olmakla birlikte, uzun süreli takip çalışmaları ile bu doğrulanmalıdır (23). Çocukluk yaş grubunda EÖ, küçük çocuklarda görülen beslenme zorluğundan büyük çocuklardaki disfaji ve besin sıkışmasına kadar değişen ilerlemeler gösterir (Şekil 2) (5).

\section{Kaynaklar}

1. Spergel JM. Eosinophilic esophagitis in adults and children: evidence for a food allergy component in many patients. Curr Opin Allergy Clin Immunol 2007; 7: 274-8. (Abstract)

2. Guajardo J, Plotnick L, Fende J, Collins MH, Putnam PE, Rohegberg ME. Eosinophil-associated gastrointestinal disorders: a world-wide-web based registry. J Pediatr 2002; 141: 576-81. Abstrac/ / Full Tex/ PDD

3. Noel RJ, Putnam PE, Rothenberg ME. Eosinofilic esophagitis. N Engl J Med 2004; 351: 940-1. Abstrac//Full Tex/ /PDA

4. Blanchard C, Wang N, Rothenberg ME. Eosinophilic esophagitis: pathogenesis, genetics, and therapy. J Allergy Clin Immunol 2006; 118: 1054-9. Abstract / Eull Tex / DDF

5. Spergel JM, Brown-Whitehorn TF, Beausoleil JL, et al. 14 years of eosinophilic esophagitis: clinical features and prognosis. J Pediatr Gastroenterol Nutr 2009; 48:30-6. Abstract / Eul Tex / PDA

6. Spergel JM, Andrews T, Brown-Whitehorn TF, Beausoleil JL, Liacouras CA. Treatmant of eosinophilic esophagitis with spesific food elimination diet directed by a combination of skin prick and patch tests. Ann Allergy Asthma Immunol 2005; 95: 336-43. Abstrad) / (PD月

7. Simon D, Marti H, Heer P, Simon HU, Breathen LR, Straumann A. Eosiniphilic esophagitis is frequently associated with $\lg \mathrm{E}-$ mediated allergic airway diseases. J Allergy Clin Immunol 2005; 115:1090-2. Abstract/Full Tex/ PDA

8. Dobbins JW, Sheahan DG, Behar J. Eosinophilic gastroenteritis with esophageal involvent. Gastroenterology 1977; 72 : 1312-6. (Abstract)

9. Kelly KJ, Lazenby AJ, Rowe PC, Yardley JH, Perman JA, Sampson HA. Eosinophilic esophagitis attributed to gastroesophageal reflux: improvement with an aminoacid-based formula. Gastroenterology 1995; 109: 1503-12. AAbstract / PDB

10. Markowitz JE, Spergel JM, Ruchelli E, Liacouras CA. Elemental diet is an effective treatment for eosinophilic esophagitis in children and adolescents. Am J Gastroenterol 2003; 98: 777-82. Abstrac / PDH

11. Liacuras CA, Spergel JM, Ruchelli E, et al. Eosinophilic esophagitis: a 10-year experience in 381 children. Clin Gastroenterol Hepatol 2005; 3: 1198-206. [Abstract / Full Text/ (PDA)

12. Assa'ad $\mathrm{AH}$, Putnam PE, Collins $\mathrm{MH}$, et al. Pediatric patients with eosinophilic esophagitis: an 8-year follow-up. J Allergy Clin Immunol 2007; 119: 731-8. Abstract / Eull Text) / (PDF) 
13. Spergel JM, Beausoleil JL, Fiedler JM, Ginsberg J, Wagner K, Pawlowski NA. Correlation of initial food reactions to observed reactions on challenges. Ann Allergy Asthma Immmunol 2004; 92: 217-24. Abstract / (PDA

14. Spergel JM, Beausoleil JL, Mascarenhas M, Liacouras CA. The use of skin prick tests and patch tests to identify causative foods in eosinophilic esophagitis. J Allergy Clin Immunol 2002; 363-8. Abstrac/ Full Tex / DDH

15. Chedade M, Aveves SS. Food allergy and eosinophilic esophagitis. Curr Opin Allergy Clin Immunol 2010; 10: 231-7. Abstract

16. Attwood S, Smyrk T, Demeester T, Jones J. Esophageal eosinophilia with dysphagia. A distinct clinicopathologic syndrome. Dig Dis Sci 1993; 38: 109-16. (Abstract)

17. Straumann A, Spichtin HP, Bernoulli R, Loosli J, Vogtlin J. Idiopathic eosinophilic esophagitis: a frequently overlooked disease with typical clinical aspects and discrete endoscopic findings. SchweizMed Wochenschr 1994; 124: 1419-29. (Abstract)

18. Desai TK, Stecevis V, Chang CH, Goldstein NS, Badizadegan K, Furuta GT. Association of eosinophilic inflammation with esophageal food impaction in adults. Gastrointest Endosc 2005; 61: 795-801. Abstract / Eull Tex / PDA

19. Croese J, Fairley SK, Masson JW, et al. Clinical and endoscopics features of eosinophilic esophagitis in adults. Gastrointest Endosc 2003; 58: 516-22. Abstrac/ (Full Tex/ PDF

20. Potter JW, Saeian K, Staff D, et al. Eosinophilic esophagitis in adults: an emerging problem with unique esophageal features.Gastrointest Endosc 2004; 59: 355-61. Abstract / Ful Tex]/PDA

21. Straumann A, Spichtin HP, Grize L, Bucher KA, Beglinger C, Simon HU. Natural history of primary eosinophilic esophagitis: a follow-up of 30 adult patients for up to 11.5 years. Gastroenterology 2003; 125: 1660-9. Abstract/ Full Text/(PDA

22. Orenstein S, Shalaby T, Lorenzo CD, Putnan P, Sigurdsson L, Kocochis S. The spectrum of pediatric eosinophilic esophagitis beyond infancy: a clinical series of 30 children. Am J Gastroenterol 2000; 95: 1422-30. Abstract

23. Strauman A, Hruz P. What's new in the diagnosis and therapy of eosinophilic esophagitis? Curr Opin Gastroenterol 2009; 25: 366-71. Abstract)

24. Furuta GT, Straumann A. Review article: the pathogenesis and management of eosinophilic esophagitis. Aliment Pharmacol Ther 2006; 24: 173-82. (Abstract) / Full Tex / PDA

25. Mungan Z, Pınarbaşı B, Kaymakoğlu S. Eosinophilic esophagitis: case report. Turk J Gastroenterol 2007; 18: 100-2. PDD

26. Straumann A, Degen L, Felder S, et al. Budesonide as induction treatment for active eosinophilic asophagitis in adolescents and adults: a randomized, double-blind, placebo-controlled study. Gastroenterology 2008; 134: A-104.

27. Walsh S. Antonioli D, Goldman H, et al. Allergic esophagitis in children-a clinicopathological entity. Am J Surg Pathol 199; 23: 390-6. Abstract

28. Straumann A, Bauer M, Ficher B, Blaser K, Simon HU. Idiopathic eosinophilic esophagitis is associated with a $\mathrm{T}(\mathrm{H}) 2$ type allergic inflammatory response. J Allergy Clin Immunol 2001; 108: 954-61. [Abstract)/ Full Tex/ PDA
29. Ruchelli E, Wenner W, Voytek T, Brown K, Liacouras C. Severity of esophageal eosinophilia predicts response to conventional gastroesophageal reflux therapy. Peditr Dev Pathol 1999; 2: 15-8. Abstract] / (PDA

30. Brigger MT, Misdraji J, Hardy SC, Hartnick CJ. Eosinophilic esophagitis in children. Arch Otolaryngol Head Neck Surg 2009; 135: 95-100. [Abstract / Full Tex] / PDA

31. Yan BM, Shaffer EA. Eosinophilic esophagitis: a newly established cause of dysphagia. World J Gastroenterol 2006; 12: 2328-34. Abstrac / Eull Tex / PDA

32. Liacouras CA, Wenner WJ, Brown K, Ruchelli E. Primary eosinophilic esophagitis in children: successful treatment with oral corticosteroids. J Pediatr Gastroenterol Nutr 1998; 26: 380-5. Abstract / Full Text

33. Orenstein SR, Shalaby TM, Di Lorenzo C, et al. The spectrum of pediatric eosinophilic esophagitis beyond infancy: a clinical series of 30 children. Am J Gastroenterol 2000; 95: 1422-30. (Abstract)

34. Gonsalves N, Policarpio-Nicolas M, Zhang Q, Rao MS, Hirano I. Histopathologic variability and endoscopic correlates in adults with eosinophilic esophagitis. Gastrointest Endosc 2006; 64: 313-9. [Abstrac] / Full Tex]/[PDF]

35. Steiner SJ, Kernek KM, Fitzgerald JF. Severity of basal cell hyperplasia differs in reflux versus eosinophilic esophagitis. $J$ Pediatr Gastroenterol Nutr 2006; 42: 506-9. Abstract)

36. Furuta GT, Liacouras CA, Collins $\mathrm{MH}$, et al. Eosinophilic esophagitis in children and adults: a systematic rewiew and consensus recommendations for diagnosis and treatment. Gastroenterology 2007; 133: 1342-63. Abstract/Full Tex/[PDF)

37. Gupte AR, Draganov PV. Eosinophilic esophagitis. World Gastroenterol 2009; 15: 17-24. Abstract Eull Tex/ PDD

38. Gupta SK. Noninvasive markers of eosinophilic esophagitis. Gastrointest Endosc Clin N Am 2008; 18: 157-67. Abstradt) / Full Tex / PDF

39. Winter HS, Madara JL, Stafford RJ, et al. Intraepithelial eosinophils: a nem diagnostic criteria for reflux esophagitis. Gastroenterology 1982; 83: 818-23.

40. Fogg MI, Ruchelli E, Spergel JM. Polen and eosinophilic esophagitis. J Allergy Clin Immunol 2003; 112: 796-7. [Full Tex / PDA

41. Özkan T, Erdemir G. Besin alerjileri. Güncel Pediatri 2006; 3: 75-9. Eull Tex / PDA

42. Teitelbaum JE, Fox VL, Twarog FT, et al. Eosinophilic esophagitis in children: immunopathological analysis and response to fluticasone propionate. Gastroenterology 2002; 122: 1216-25. Abstract/ Full Tex / DDA

43. Konikoff MR, Noel RJ, Blanchard C, et al. A randomized, doubleblind, placebo-controlled trial of fluticasone propionate for pediatric eosinophilc esophagitis. Gastroenterology 2006; 131: 1381-91. Abstract/ Full Tex / PDA

44. Schaafer ET, Fitzgerald JF, Molleston JP, et al. Comparison of oral prednisone and topical fluticasone in the treatment of eosinophilic esophagitis; a randomized trial in children. Clin Gastroenterol Hepatol 2008; 6: 165-73.

45. Netzer P, Gschossman KM, Straumann A, et al. Corticosteroid-dependent eosinophilic oesophagitis: azathioprine and 6-mercaptopurine can induce and maintain longterm remission. Eur J Gastroenterol Hepatol 2007; 19: 865-9. Abstract/Full Tex / PDA 